\title{
IMPLEMENTASI METODE PROBLEM BASED LEARNING DALAM UPAYA MENINGKATKAN HASIL BELAJAR AKUNTANSI
}

\author{
Elisabeth Warniningsih \\ SMA Negeri 1 Pengasih Kulon Progo \\ elisswarniningsih@gmail.com
}

\begin{abstract}
Abstrak: Penelitian ini bertujuan untuk mendapatkan cara meningkatkan hasil belajar akuntansi bagi siswa dengan menggunakan metode Belajar Pemecahan Masalah/ Problem Based Learning mata pelajaran Akuntansi SMAN 1 Pengasih. Penelitian ini merupakan penelitian tindakan kelas dengan pendekatan deskriptif kualitatif yang dilaksanakan dalam dua siklus dengan tiga pertemuan pada masing-masing siklusnya. Dengan 22 siswa yang berpartisipasi sebagai subjek dalam penelitian ini. Setiap pertemuan menggunakan langkah-langkah sebagai berikut: perencanaan, tindakan, dan refleksi. Instrumen pengumpulan data dalam penelitian ini adalah angket, lembar observasi, catatan lapangan, skala sikap, dan tes hasil belajar (ulangan harian). Dari hasil penelitian menunjukkan bahwa dengan menggunakan metode Problem Based Learning Proses pembelajaran menjadi lebih efektif, aktivitas siswa selama proses pembelajaran juga lebih efektif, menyenangkan, dan riang. Metode Problem Based Learning ini berpengaruh positif terhadap peningkatan hasil belajar siswa di bidang akuntansi yang dapat diketahui dari: (a) peningkatan aktivitas siswa dan motivasi siswa pada siklus I dan II; (b) peningkatan hasil belajar siswa pada aspek kognitif (standar ketuntasan belajar siswa dari 77,53\% pada siklus I dan 82,63\% pada siklus II), Serta pada aspek afektif dari tingkat cukup menjadi sangat baik pada akhir pembelajaran. Hasil pembelajaran ini juga didukung oleh penilaian dalam proses pembelajaran yang diadakan oleh kolaborator, dari klasifikasi $50 \%$ baik menjadi 50\% sangat baik.
\end{abstract}

Kata kunci: Metode $P B L$, Ekonomi Akuntansi

\section{IMPLEMENTATION OF PROBLEM BASED LEARNING METHOD IN EFFORTS TO IMPROVE ACCOUNTING LEARNING RESULTS}

\begin{abstract}
This study to find a way to increase the student achievement in studying accounting by using Problem Based Learning of SMAN 1 Pengasih. This study was a classroom action research with qualitative descriptive approach. This study conducted in two cycle whith three meetings in each cycle. There were 22 students participated as subject in this study. Each meeting applied the following steps: planning, action, and reflection. The data collecting instruments in this study were questionnaire, observation sheets, field note, attitude scale, and achievement test (daily test). The result of this study indicates that by using Problem Based Learning, the learning process became more effective, the student activity during the learning process also more effective, enjoyable, and joyful. The method has positive effect of increasing the student achievement in accounting that can be known from: (a) the increase of student activity and students motivation in cycle I and II; (b) the increase of students achievement in cognitive aspect (student learning completeness standard from $77.53 \%$ in cycle I and $82.63 \%$ in cycle II), and in affective aspect from the level of enough become excellent in the end of the study. Result of the study also supported by the assessment in learning process which was held by the collaborator, from the classification of 50\% good to $50 \%$ excellent.

Keywords: PBL method, economy accounting
\end{abstract}

\section{PENDAHULUAN}

Pendidikan memegang peranan penting dalam kehidupan seseorang atau suatu bangsa. Kemajuan pembangunan suatu bangsa dapat dicapai dan pendidikan yang terarah dan berkesinambungan. Melalui pendidikan diciptakan manusia yang berakhlak mulia, cerdas, unggul, berbudaya dan berkepribadian. Untuk mewujudkan tujuan pendidikan yang benar pemerintah menetapkan Undang undang nomor 20 Tahun 2003 tentang Sistem Pendidikan Nasional yang penjabarannya pada pembelajaran di sekolah-sekolah.

Pada era globalisasi ini, perkembangan teknologi yang semakin maju. Kemajuan teknologi ini membuat manusia semakin mudah memperoleh berbagai informasi, misalnya informasi terbaru dari bursa efek gabungan, 
laporan keuangan suatu perusahaan, laporan RAKS, namun demikian kemajuan teknologi juga memiliki dampak negatif, misalnya siswa dengan mudah memperoleh contoh laporan keuangan suatu perusahaan, hal ini juga terjadi pada siswa SMAN 1 Pengasih menyebabkan siswa belajarnya menjadi rendah, pasif, dan tidak kreatif sehingga hasil belajar rendah, khususnya mata pelajaran akuntansi yang banyak hitungan. Permasalahan seperti ini akan terus berlanjut jika tidak segera diatasi dengan metode pembelajaran yang tepat dengan kondisi siswa, agar tercipta pembelajaran yang menarik, menyenangkan dan bermakna. Upaya dalam mewujudkan metode pembelajaran menjadi menarik, menyenangkan, mudah diterima, dan mudah difahami, maka penerapan inovasi suatu metode pembelajaran akuntansi harus tepat, sehingga hasil yang diharapkan adalah hasil belajar akuntansi meningkat, dengan kata lain tercapai ketuntasan belajarnya.

Permasalahan di atas memotivasi peneliti untuk mengadakan penelitian tindakan kelas yang berkaitan dengan implementasi metode Problem Based Learning dalam upaya meningkatkan hasil belajar akuntansi pada siswa SMAN 1 Pengasih, berkolaborasi dengan teman sejawat dan pengawas ekonomi, harapannya dapat meningkatkan hasil belajar siswa. Problem Based learning yakni metode pembelajaran yang berbasis teori belajar konstruktivistik yang dikenalkan oleh John Dewey. Secara umum pembelajaran berdasarkan masalah terdiri dari menyajikan kepada siswa situasi masalah yang otentik dan bermakna yang dapat memberikan kemudahan kepada mereka untuk melakukan penyelidikan dan inkuiri.

\section{LANDASAN TEORI}

Problem Based Learning adalah salah satu metode pembelajaran yang diharapkan dapat meningkatkan keaktifan siswa adalah metode problem based learning. Metode ini mempersiapkan siswa untuk berpikir kritis dan analitis, untuk mencari serta menggunakan sumber pembelajaran yang sesuai (Amir, 2010: 21). Dalam metode problem based learning, sebelum pelajaran dimulai, siswa diberikan masalahmasalah. Masalah yang disajikan adalah masalah yang memiliki konteks dengan dunia nyata, semakin dekat dengan dunia nyata, maka akan semakin baik pengaruhnya pada peningkatan kecakapan pada siswa. Dari masalah yang diberikan ini siswa kemudian bekerjasama dalam kelompok, mencoba memecahkan masalah dengan kemampuan yang dimiliki, dan sekaligus mencari informasi-informasi baru yang relevan. Disini peran guru adalah sebagai fasilitator yang mengarahkan siswa dalam mencari dan menemukan solusi dan sekaligus menentukan kriteria pencapaian proses pembelajarannya. Proses utama dalam problem based learning terletak pada diri siswa. Variabel dari luar hanya intruksi yang membantu atau membimbing siswa dalam menyelesaikan masalah. Hasil belajar yang diperoleh sukar dilupakan dan dapat dimanfaatkan pada berbagai situasi yang termasuk dalam kategori tertentu. Kemampuan memecahkan masalah merupakan hasil belajar yang sangat penting dan harus dikuasai oleh siswa disamping hasil belajar pada aspek kognitif. Problem Based Learning dikembangkan untuk membantu siswa mengembangkan kemampuan berpikir, mengatasi masalah, keterampilan penyelidikan, kemampuan mempelajari peran sebagai orang dewasa melalui keterlibatan mereka dalam pengalaman nyata atau simulasi, dan menjadi pembelajar yang mandiri dan independen. Problem based learning lebih dari sekedar lingkungan yang efektif untuk pengetahuan tertentu. Pengetahuan riil bagi para siswa adalah sesuatu yang dibangun atau ditemukan oleh siswa itu sendiri. Jadi pengetahuan bukanlah seperangkat fakta, konsep atau kaidah yang diingat siswa, tetapi harus merekonstruksi pengetahuan itu kemudian memberi makna melalui pengalaman nyata. Dalam pembelajaran ini siswa harus dilatih untuk memecahkan masalah, menemukan sesuatu yang berguna bagi dirinya dan bergulat dengan ide-ide dan kemudian mampu merekonstruksinya. Dari beberapa metode mengajar yang ada, metode Problem Based Learning lebih banyak memiliki keunggulan, baik dari segi sifat materi, tujuan, serta kemampuan yang dapat dimiliki siswa.

Hasil belajar Menurut Suprijono (2012:5), hasil belajar adalah polapola perbuatan, nilainilai, pengertian-pengertian, sikapsikap, apresiasi dan keterampilan. Selanjutnya Supratiknya (2012: 5) mengemukakan bahwa hasil belajar yang menjadi objek penilaian kelas berupa kemampuan-kemampuan baru yang diperoleh siswa setelah mereka mengikuti proses belajar-mengajar tentang mata pelajaran tertentu. Dalam sistem pendidikan nasional 
rumusan tujuan pendidikan mengacu pada klasifikasi hasil belajar dari Bloom yang secara garis besar yaitu aspek kognitif, aspek afektif dan aspek psikomotor.

Aktivitas belajar Berbuat untuk merubah tingkah laku melalui perbuatan adalah prinsip belajar. Ada atau tidaknya belajar dicerminkan dari ada atau tidaknya aktivitas. Tanpa ada aktivitas, belajar tidak mungkin terjadi. Sehingga dalam interaksi belajar-mengajar aktivitas merupakan prinsip yang penting. Penggunaan metode, pendekatan belajar mengajar dan orientasi belajar menyebabkan aktivitas belajar setiap siswa berbeda-beda. Ketidaksamaan aktivitas belajar siswa melahirkan kadar aktivitas belajar yang bergerak dari aktivitas belajar yang rendah sampai aktivitas belajar yang tinggi.

Penelitian ini merupakan penelitian tindakan kelas (classroom action research), yang berfokus pada upaya untuk mengubah kondisi riil sekarang ke arah kondisi yang diharapkan (improvement oriented). Penelitian ini dilakukan secara kolaboratif dan siklik dalam dua siklus, yakni perenungan untuk menentukan masalah, perencanaan (planning), tindakan (acting), dan observasi (observing), serta refleksi (reflecting). Penelitian ini merupakan Penelitian Tindakan Kelas (PTK) seperti yang diketengahkan oleh Burns (1999:29-30) mengutip pendapat beberapa para ahli yang terkenal yang dikemukakan oleh Carr dan Kemmis bahwa: penelitian tindakan merupakan suatu bentuk penelitian yang bersifat reflektif yang dilakukan oleh guru dalam masyarakat sosial dan bertujuan untuk memperbaiki pekerjaanya, memahami pekerjaan, dan situasi pekerjaan itu dilakukan. Kemmis dan McTaggart (Burns, 1999: 13) menyatakan pentingnya kolaboratif dalam penelitian tindakan. Permasalahan yang dipecahkan harus didiskusikan dengan seluruh anggota yang terlibat. Kolaborasi di sini berarti seluruh anggota yang terlibat aktif memberikan kontribusi terhadap bentuk tindakan yang dilakukan untuk membuat perubahan atas permasalahan yang terjadi. Dengan dasar teori tersebut maka penelitian ini dilaksanakan dengan bersiklus yang meliputi refleksi awal (reconnaissance) dan perencanaan, tindakan, observasi dan refleksi I, rencana terevisi I, tindakan dan observasi II, refleksi II, dilanjutkan rencana terevisi II, tindakan III, refleksi III, serta triangulasi dan membuat laporan penelitian.
Penelitian dilaksanakan pada akhir bulan September 2019 sampai dengan bulan Nopember 2019, menggunakan Penelitian Tindakan Kelas PTK, pada mata pelajaran Ekonomi Akuntansi yang menjadi mata pelajaran di kelas XII kurikulum 2013.

Target dalam penelitian ini adalah siswa kelas XII di SMAN 1 Pengasih Kulon Progo, dengan populasi sebanyak 22 siswa yang pada semester Genap akan menghadapi Ujian Akhir Sekolah Berstandar Nasional, sehingga diupayakan perbaikan proses pembelajarannya dapat tercapai ketuntasan belajar akuntansi serta dampak selanjutnya nilai Ujian Akhir Sekolah Berstandar Nasional diatas rata-rata tingkat Propinsi

Penelitian ini ditujukan untuk meningkatkan hasil belajar Akuntansi melalui metode Problem Based Learning pada siswa di SMA N 1 Pengasih Kulon Progo. Alasan dipilihnya tempat tersebut adalah peneliti ingin meningkatkan kinerjanya sebagai guru, serta ingin meningkatkan keaktifan siswa yang selama ini masih sulit terwujud serta ingin meningkatkan hasil belajar siswa.

\section{METODE PENELITIAN}

Instrumen yang digunakan untuk penelitian dan teknik pengumpulan data adalah instrumen proses dan hasil. Instrumen proses adalah instrumen untuk mengetahui efektif tidaknya proses pembelajaran ekonomi. Instumen hasil adalah instrumen untuk mengetahui hasil belajar siswa.

Instrumen tersebut meliputi: 1) Instrumen untuk mengetahui efektif tidaknya proses pembelajaran dengan menilai aspek perencanaan pembelajaran, dan aspek afektif pada saat proses pembelajaran dengan mind mapping berlangsung (dilakukan oleh kolaborator menggunakan lembar observasi). 2) Instrumen untuk mengetahui hasil belajar ekonomi siswa dengan butir soal atau ulangan harian (dilakukan oleh guru peneliti menggunakan lembar soal/ulangan).

Teknik pengumpulan data pada penelitian ini bersumber pada:

1. Observasi kelas

Observasi digunakan untuk memperoleh data tentang perilaku siswa dan perilaku guru (peneliti) selama berlangsungnya proses pembelajaran ekonomi. Observasi ini untuk mengetahui perubahan yang terjadi pada proses pembelajaran ekonomi baik sebelum maupun sesudah dilakukan tindakan penelitian. Observasi ini dilakukan oleh kolaborator. Observasi kelas 
juga didukung dengan fotografi. Hasil observasi kelas berupa catatan lapangan dan foto, serta data berupa angka-angka Skala Perbedaan Semantik (SPS).

2. Wawancara

Wawancara dilakukan untuk mengetahui data tentang perilaku siswa dan perilaku guru peneliti selama dan sesudah proses pembelajaran ekonomi. Wawancara yang dilakukan berupa wawancara terencana tetapi tak terstruktur. Pada awal wawancara diberikan satu dua pertanyaan sebagai pembuka, dilanjutkan dengan memberikan kesempatan kepada responden untuk menjawab pertanyaan secara terbuka. Pewawancara mengajukan pertanyaan untuk menggali dan memperjelas adanya perubahan proses pembelajaran sebelum dan sesudah dilakukan tindakan. Wawancara dilakukan oleh guru (peneliti) kepada siswaI di SMA N 1 Pengasih, dan kolaborator.

3. Tes (Ulangan Harian).

Tes (ulangan harian) untuk mengetahui hasil belajar ekonomi siswa sekaligus tingkat ketuntasan belajar ekonomi siswa. Ulangan harian dilaksanakan setiap akhir siklus, dan hasil ulangan dianalisis untuk mengetahui daya serap siswa sekaligus ketuntasan belajar siswa baik secara individual maupun klasikal.

Kriteria ketuntasan mata pelajaran ekonomi akuntansi di SMA N 1 Pengasih adalah 70. Bagi para siswa yang sudah mencapai nilai $70 \mathrm{ke}$ atas maka sudah dikatakan tuntas, dan siswa yang mendapatkan nilai ulangan kurang dari 70 maka dilaksanakan perbaikan (remidial). Siswa-siswa yang sudah tuntas diberikan pengayaan.

Teknik Analisis Data adalah data penelitian yang berupa data kualitatif dianalisis dan catatan lapangan dan transkip hasil wawancara. Data penelitian yang berupa data kuantitatif dianalisis secara diskriptif analitik yang bersifat eksplanatorik, yaitu dengan penyajian tabel-tabel, dan persentase. Penyajian data dalam bentuk persentase selanjutnya didiskripsikan dan diambil kesimpulan tentang masing-masing komponen. Untuk mendukung keberhasilan proses pembelajaran sekaligus ketuntasan belajar atau hasil belajar siswa diadakan tes (ulangan harian). Hasil tes dianalisis untuk mengetahui daya serap siswa sekaligus ketuntasan belajar siswa. Untuk menghindari subjektivitas, peneliti menggunakan triangulasi yaitu teknik pemeriksaan data dengan memanfaatkan sesuatu yang lain di luar data.

Adapun langkah-langkah analisisnya sebagai berikut:
1. Analisis penilaian proses pembelajaran dengan jumlah butir instrumen penilaian proses pembelajaran 20 pertanyaan dengan pilihan jawaban model skala perbedaan semantik. Skor yang diberikan adalah 1 sampai 5, dengan kategori sebagai berikut:

- $\quad$ skala $5=$ sangat baik,

- $\quad$ skala $4=$ baik,

- $\quad$ skala $3=$ cukup,

- $\quad$ skala 2 = kurang,

- $\quad$ skala 1 = sangat kurang.

Hal ini berarti skor ideal tertinggi 100 dan skor ideal terendah 20, dan ditentukan prosentase pada setiap kategori.

2. Analisis penilaian aspek afektif siswa dengan jumlah butir instrumen penilaian aspek afektif siswa 6 pertanyaan dengan pilihan jawaban model skala perpedaan semantik. Skor yang diberikan adalah 1 sampai 5, dengan kategori sebagai berikut:

- skala 5 = sangat baik,

- skala 4 = baik,

- skala 3 = cukup,

- skala 2 = kurang,

- skala 1 = sangat kurang.

Hal ini berarti skor ideal tertinggi 30 dan skor ideal terendah 6 .

\section{PROSEDUR PENELITIAN}

1. Refleksi Awal

Pada tahap ini peneliti bersama kolaborator mengadakan observasi kelas awal untuk melihat keadaan proses pembelajaran sebelum diberi tindakan dan menyusun skenario pembelajaran yang akan diimplementasikan di kelas. Skenario tindakan pembelajaran meliputi tujuan, jenis kegiatan guru dan siswa, draf pembelajaran, draf instrumen perekam data, maupun teknis pelaksanaannya.

2. Perencanaan

Setelah dilakukan observasi awal, selanjutnya peneliti merencanakan skenario pembelajaran dan menyiapkan fasilitas dan sarana pendukung untuk melaksanakan skenario tindakan. Setelah seluruh fasilitas yang dibutuhkan siap, rencana tindakan disimulasikan untuk mereduksi kesalahan sekecil mungkin dan memberikan gambaran konkrit tindakan yang akan dilakukan terutama dalam KD permintaan dan penawaran sehingga terjadi harga keseimbangan pasar.

Kegiatan yang akan dilakukan pada tahap ini adalah membuat skenario pembelajaran, menyiapkan media, menyiapkan instumen 
observasi serta wawancara, menyiapkan kegiatan refleksi guna menemukan pemecahan masalah pada siklus berikutnya.

\section{Pelaksanaan}

Pada tahap ini skenario pembelajaran diimplementasikan di kelas. Proses pembelajaran dengan menggunakan model pembelajaran Problem Based Learning dilakukan di kelas XII SMAN 1 Pengasih. Pada saat tindakan berlangsung, kolaborator melakukan observasi dengan menggunakan instrumen yang telah disediakan. Kolaborator mencatat data yang ada, dan juga diminta untuk memberikan interprestasinya atas berbagai masalah yang dijumpai. Untuk memudahkan kolaborator dalam memberikan penilaian, peneliti telah menyediakan instrumen dalam bentuk Skala Perbedaan Semantik (SPS), dan catatan lapangan secara terbuka. Peneliti selain melakukan tindakan juga mencatat berbagai reaksi siswa pada saat tindakan berlangsung.

\section{Refleksi}

Hasil observasi kelas, rekaman data, diskusi balikan dan berbagai temuan yang lain, dibawa ke forum refleksi untuk dianalisis oleh semua peserta penelitian secara bersama-sama.

Hasil analisis tersebut kemudian digunakan untuk merencanakan kagiatan pada siklus berikutnya. Tindakan yang berhasil dilanjutkan pada proses pembelajaran berikutnya, sedangkan tindakan yang tidak berhasil diubah dan diperbaiki.

\section{Kriteria Keberhasilan}

Pembelajaran yang efektif dapat dilihat apabila siswa semakin bergairah, aktif, konsentrasi, saling berdiskusi dan tidak saling cekcok dan ingin pelajaran terus berlangsung. Menurut Bloom (Block, 1971: 3), prinsip belajar tuntas (mastery learning) adalah suatu sistem belajar yang mengharapkan sebagian siswa dapat menguasai tujuan instruksional umum dan unit pelajaran secara tuntas.

Standar penguasaan tuntas itu yaitu $75 \%$ 90\% dari semua siswa menguasai tujuan instruksional. Penelitian ini dikatakan berhasil jika $75 \%$ siswa telah mencapai Kriteria Ketuntasan Minimal (KKM).

\section{HASIL DAN PEMBAHASAN Siklus I}

Proses pembelajaran menggunakan Problem Based Learning tatap muka I, siklus I ini, belum begitu tampak adanya perubahan yang berarti pada komponen-komponen yang diamati seperti sikap siswa dalam kelompok, partisipasi, perilaku, dan interaksi antar siswa. Problem Based Learning juga belum berfungsi, karena ada beberapa siswa masih kelihatan bingung dalam memahami materi yang ada pada Problem Based Learning, masih membuka-buka buku paket, atau LKS.

Pembelajaran masih didominasi oleh guru. Untuk menentukan kategori penilaian proses pembelajaran dan penilaian aspek afektif yaitu ditentukan persentase pada setiap kategori penilaian. Dan hasil analisis data penilaian proses pembelajaran dan analisis data penilaian aspek afektif siswa dapat diketahui masing-masing kategorinya.

Data yang diperoleh dari kedua kolaborator pada proses pembelajaran tatap muka I, Siklus I, sebagai berikut:

1. Penilaian Proses Pembelajaran

Berdasarkan penilaian kolaborator terhadap proses pembelajaran dengan $P B L$ kolaborator memberikan jumlah skor 66, aspek pengamatan atau $66: 20=3,3$, maka penilaian proses pembelajaran kategorinya cukup. Distribusi frekuensi skor dapat dilihat pada tabel 1 berikut.

Tabel 1. Rekapitulasi Penilaian Proses Pembelajaran

\begin{tabular}{clcc}
\hline No. & Kategori & Frekuensi & Persentase (\%) \\
\hline 1 & Sangat Baik & 0 & 0 \\
2 & Baik & 5 & 25 \\
3 & Cukup & 15 & 75 \\
4 & Kurang & 0 & 0 \\
5 & Sangat Kurang & 0 & 0 \\
\hline & Jumlah & 20 & 100 \\
\hline
\end{tabular}

Berdasarkan tabel 1, hasil penilaian oleh kolaborator terhadap proses pembelajaran terdapat pada kategori cukup sebesar $75 \%$ dan $25 \%$ baik.

2. Penilaian Aspek Afektif Siswa

Berdasarkan penilaian kolaborator terhadap aspek afektif siswa (instrumen II), diperoleh rata-rata jumlah skor 18 (lihat lampiran). Untuk menentukan kategori penilaian aspek afektif siswa jumlah skor ratarata dibagi jumlah aspek pengamatan (18:6 = 3), maka kategorinya cukup.

Refleksi dari kolaborator pada tatap muka I, siklus I antara lain: problem based learning hendaknya difungsikan secara maksimal, diciptakan interaksi antar siswa, pemberian motivasi perlu ditingkatkan, pemberian pujian (reward) perlu ditingkatkan, pengelolaan kelas perlu ditingkatkan, menejemen waktu 
perlu diperhatikan agar pretes dan post tes dapat terlaksana dengan baik.

Tatap muka 2, siklus I, keaktifan siswa sudah mengalami peningkatan dibanding tatap muka sebelumnya, walaupun masih ada beberapa siswa yang masih cenderung diam, Problem Based Learning sudah mulai berfungsi, siswa sesekali saja membuka buku paket apabila di dalam Problem Based Learning belum tertulis. Dalam presentasi sudah ada beberapa siswa yang mau menanggapi hasil diskusi kelompok lain, manajemen waktu masih kurang sehingga belum semua kelompok mempresentasikan hasil diskusinya, namun demikian sudah ada peningkatan dibanding sebelumnya.

Refleksi tatap muka 2, siklus I, oleh kolaborator bersama peneliti bahwa proses pembelajaran dengan Problem Based Learning sudah menunjukkan tanda-tanda perbaikan, hal ini dapat dilihat dari beberapa indikator yaitu banyak siswa yang aktif. Pendekatan guru dalam memantau dan mengamati siswa dengan teknik chennel sudah cukup baik, situasi pembelajaran nyaman. Manajemen waktu perlu ditingkatkan, pemberian motivasi juga perlu ditingkatkan, dan guru hendaknya menyampaikan kesimpulan.

Peningkatan proses pembelajaran juga dapat dilihat dari hasil analisis penilaian proses pembelajaran, keaktifan siswa juga dapat dilihat dari hasil analisis lembar observasi penilaian aspek afektif siswa, sebagai berikut:

\section{Penilaian Proses Pembelajaran}

Berdasarkan penilaian kolaborator terhadap proses pembelajaran Problem Based Learning (menggunakan instrumen I), kolaborator memberikan jumlah skor 70 . Untuk menentukan kategori penilaian adalah jumlah butir aspek pengamatan atau 70:20= 3,5, maka penilaian proses pembelajaran kategorinya cukup. Distribusi frekuensi skor terdapat pada tabel 2 berikut.

Tabel 2. Rekapitulasi Penilaian Proses Pembelajaran

\begin{tabular}{clcc}
\hline No. & Kategori & Frekuensi & Persentase (\%) \\
\hline 1 & Sangat Baik & 0 & 0 \\
2 & Baik & 10 & 50 \\
3 & Cukup & 10 & 50 \\
4 & Kurang & 0 & 0 \\
5 & Sangat Kurang & 0 & 0 \\
\hline & Jumlah & 20 & 100 \\
\hline
\end{tabular}

Berdasarkan tabel 2, basil penilaian oleh kolaborator terhadap proses pembelajaran terdapat pada kategori cukup sebesar $50 \%$ dan 50 baik.

\section{Penilaian Aspek Afektif Siswa}

Berdasarkan penilaian kolaborator terhadap aspek afektif siswa (instrumen $\mathrm{H}$ ), diperoleh jumlah skor rata-rata 20,8 (lihat lampiran). Untuk menentukan kategori penilaian aspek afektif siswa, jumlah skor ratarata dibagi jumlah aspek pengamatan (20,8:6 $=3,46$ ), maka kategorinya cukup.

Refleksi dari kolaborator pada tatap muka 2, siklus I dapat kita rangkum dan kita fokuskan pada: Problem Based Learning hendaknya difungsikan secara maksimal, diciptakan interaksi antar siswa, pemberian motivasi agar siswa aktif perlu ditingkatkan, pemberian pujian (reward) atau sekedar doorprice perlu ditingkatkan, pengelolaan kelas perlu ditingkatkan, menejemen waktu perlu diperhatikan agar pretes dan post tes dapat dilaksanakan dengan baik.

Tatap muka 3, siklus I, keaktifan siswa sudah mengalami peningkatan dibanding tatap muka sebelumnya, walaupun masih ada beberapa siswa yang masih cenderung diam, Problem Based Learning sudah mulai berfungsi, siswa sesekali saja membuka buku paket apabila di dalam Problem Based Learning belum tertulis. Dalam presentasi banyak siswa yang mau menanggapi hasil diskusi kelompok lain, manajemen waktu masih kurang sehingga belum semua kelompok mempresentasikan hasil diskusinya, namun demikian sudah ada peningkatan dibanding sebelumnya.

Refleksi tatap muka 3, siklus I, oleh kolaborator bersama peneliti sebagai berikut: proses pembelajaran dengan Problem Based Learning sudah menunjukkan tanda-tanda perbaikan, hal ini dapat dilihat dan beberapa indicator yaitu banyak siswa yang aktif. Pendekatan guru dalam memantau dan mengamati siswa dengan teknik chennel sudah cukup baik, situasi pembelajaran nyaman. Manajemen waktu perlu ditingkatkan, pemberian motivasi juga perlu ditingkatkan, dan siswa yang membuat kesimpulan. Peningkatan proses pembelajaran juga dapat dilihat dari basil analisis penilaian proses pembelajaran, keaktifan siswa juga dapat dilihat dan basil analisis lembar observasi penilaian aspek afektif siswa. sebagai berikut: 
1. Penilaian Proses Pembelajaran

Berdasarkan penilaian kolaborator terhadap proses pembelajaran Problem Based Learning (menggunakan instrumen I), kolaborator memberikan jumlah skor 78. Untuk menentukan kategori penilaian adalah rata-rata jumlah skor dari kolaborator dibagi jumlah butir aspek pengamatan atau 78:20 =3,9, maka penilaian proses pembelajaran kategorinya baik. Distribusi frekuensi skor terdapat pada tabel 3 berikut.

Tabel 3. Rekapitulasi Penilaian Proses Pembelajaran

\begin{tabular}{cllc}
\hline No. & Kategori & Frekuensi & Persentase (\%) \\
\hline 1 & Sangat Baik & 2 & 10 \\
2 & Baik & 14 & 70 \\
3 & Cukup & 4 & 20 \\
4 & Kurang & 0 & 0 \\
5 & Sangat Kurang & 0 & 0 \\
\hline & Jumlah & 20 & 100 \\
\hline
\end{tabular}

Berdasarkan tabel 3, hasil penilaian oleh kolaborator terhadap proses pembelajaran terdapat pada kategori cukup sebesar $20 \%$ dan $70 \%$ baik.

\section{Penilaian Aspek Afektif Siswa}

Berdasarkan penilaian kolaborator terhadap aspek afektif siswa (instrumen II), diperoleh jumlah skor rata-rata 22,5 (lihat lampiran). Untuk menentukan kategori penilaian aspek afektif siswa, jumlah skor ratarata dibagi jumlah aspek pengamatan $(22,5: 6=$ $3,75)$, maka kategorinya cukup.

Refleksi dan kolaborator pada tatap muka 3 , siklus I dapat kita rangkum dan kita fokuskan pada: Problem Based Learning hendaknya difungsikan secara maksimal, diciptakan interaksi antar siswa, pemberian motivasi agar siswa aktif perlu ditingkatkan, pemberian pujian (reward) atau sekedar doorprice perlu ditingkatkan, pengelolaan kelas perlu ditingkatkan, menejemen waktu perlu diperhatikan agar pretes dan post tes dapat dilaksanakan dengan baik.

Ketuntasan belajar siswa juga dapat diketahui hasil ulangan aspek kognitif (ulangan harian) pada siklus I, diperoleh nilai terendah 60 , nilai tertinggi 87 , dan nilai rerata 72,53 , sehingga daya serap siswa secara klasikal $72,53 \%$. Pencapaian daya serap siswa pada siklus I ini belum tuntas baik secara individual maupun klasikal, sehingga bagi siswa yang belum tuntas diadakan perbaikan (remidial). Bagi siswa yang sudah tuntas dapat membantu belajar siswa yang belum tuntas dengan cara tutor sebaya. Daya serap hasil ulangan harian dapat dilihat pada lampiran.

Berdasarkan hasil refleksi yang dilakukan peneliti dan kolaborator, dapat disimpulkan bahwa ada beberapa permasalahan yang muncul pada saat proses pelaksanaan tindakan siklus I, dan disepakati untuk mengadakan beberapa revisi pada rancangan tindakan siklus I yang sekaligus menjadi rancangan tindakan siklus II. Adapaun tindakan yang direncanakan untuk siklus II masih sama dengan tindakan siklus I namun ada beberapa hal yang perlu direvisi meliputi: 1) Dalam memotivasi siswa agar aktif hendaknya lebih ditingkatkan, 2) Pengelolaan kelas lebih ditingkatkan, 3) Pemberian umpan balik (feed back) lebih ditingkatkan, 4) Manajemen waktu dalam proses pembelajaran perlu diperhatikan.

\section{Siklus II}

Tindakan-tindakan utama pada siklus I tetap dipertahankan, diharapkan tindakan siklus II ini siswa semakin siap dan dapat memahami konsep dengan baik, nyaman dalam belajar, senang belajar ekonomi dan dampak positifnya meningkatkan hasil belajar ekonomi. Seperti halnya siklus I pelaku tindakan adalah guru ekonomi sebagai peneliti dan dibantu dua orang kolaborator serta foto grafer yang mendokumentasikan kegiatan pembelajaran. Pada siklus ke II ini juga direncanakan dua kali tatap muka.

Keberhasilan tindakan siklus II diindikasikan adanya perubahan-perubahan yang lebih baik (meningkat), pada komponen yang diamati yaitu aspek sikap (kerajinan, perhatian, keaktifan, kerapian ketepatan dan kebenaran). Pada proses pembelajaran peningkatan tersebut akan terlihat jelas terutama pada keaktifan siswa, serta hasil analisis aspek afektif siswa tersebut. Sedangkan untuk mengetahui ketuntasan belajar siswa diadakan ulangan harian dan sekaligus dianalisis untuk mengetahi daya serap siswa.

Pada siklus II, tatap muka 1, para siswa sudah semakin siap dengan $P B L$ dibanding siklus I, terlihat para siswa sudah menggelar Problem Based Learning di atas meja di setiap kelompok. Sebelum diskusi kelompok di mulai guru memberikan pertanyaan sebagai pretest untuk mengetahui sejauhmana kesiapan siswa pada materi yang akan dibahas

Proses pembelajaran menggunakan Problem Based Learning tatap muka I, siklus II ini, sudah tampak adanya perubahan yang 
berarti pada komponen-komponen yang diamati seperti sikap siswa dalam kelompok, partisipasi, perilaku, dan interaksi antar siswa. Problem Based Learning sudah berfungsi, beberapa siswa antusias memahami materi yang ada pada Problem Based Learning, tinggal beberapa siswa yang membuka-buka buku paket, para siswa sudah memanfaatkan Problem Based Learning

Disamping catatan lapangan yang berupa diskripsi, juga didukung hasil analisis penilaian proses pembelajaran, dan hasil analisis penilaian aspek afektif siswa. Untuk menentukan kategori penilaian proses pembelajaran dan penilaian aspek afektif siswa yaitu ditentukan persentase pada setiap kategori penilaian. Dari hasil analisis data penilaian proses pembelajaran dan analisis data penilaian aspek afektif siswa dapat diketahui masing-masing kategorinya.

Data yang diperoleh dan kedua kolaborator pada proses pembelajaran tatap muka I, siklus II, sebagai berikut:

\section{Penilaian Proses Pembelajaran}

Berdasarkan penilaian kolaborator terhadap proses pembelajaran dengan Problem Based Learning, kolaborator memberikan jumlah skor 84. Untuk menentukan kategori penilaian adalah jumlah butir aspek pengamatan atau 84:20 $=4,2$ maka penilaian proses pembelajaran kategorinya baik. Distribusi frekuensi skor dapat dilihat pada tabel 4 berikut.

Tabel 4. Rekapitulasi Penilaian Proses

$$
\text { Pembelajaran }
$$

\begin{tabular}{llcc}
\hline No. & Kategori & Frekuensi & Persentase (\%) \\
\hline 1 & Sangat Baik & 4 & 20 \\
2 & Baik & 16 & 80 \\
3 & Cukup & 0 & 0 \\
4 & Kurang & 0 & 0 \\
5 & Sangat Kurang & 0 & 0 \\
\hline & Jumlah & 20 & 100 \\
\hline
\end{tabular}

Berdasarkan tabel 4, hasil penilaian oleh kolaborator terhadap proses pembelajaran terdapat pada kategori $80 \%$ baik.

\section{Penilaian Aspek Afektif Siswa}

Berdasarkan penilaian kolaborator terhadap aspek afektif siswa (instrumen II), diperoleh jumlah skor rata-rata adalah 24 . Untuk menentukan kategori penilaian aspek afektif siswa jumlah skor rrata-rata dibagi jumlah aspek pengamatan $(24: 6=4)$, maka kategorinya baik.

Refleksi dari kolaborator pada tatap muka 1, siklus II dapat kita rangkum dan kita fokuskan pada: Problem Based Learning difungsikan secara maksimal, diciptakan interaksi antar siswa, pemberian motivasi agar siswa aktif perlu ditingkatkan, pengelolaan kelas perlu ditingkatkan, menejemen waktu baru selalu diperhatikan.

Tatap muka 2, siklus II, keaktifan siswa sudah mengalami peningkatan yang signifikan, Problem Based Learning sudah mulai berfungsi, siswa sesekali saja membuka buku paket dan LKS apabila di dalam Problem Based Learning belum tertulis. Dalam presentasi sudah banyak siswa yang menanggapi hasil diskusi kelompok lain, manajemen waktu sudah bagus sehingga hampir semua kelompok mempresentasikan hasil diskusinya. Hal ini sesuai dengan pengamatan yang dapat dirangkum sebagai berikut: interaksi antar siswa dalam kelompok Problem Based Learning sudah baik, siswa aktif menjawab pertanyaan baik dari guru maupun temannya. Guru mampu membawa proses pembelajaran dalam situasi inti dan menyenangkan. Diskusi sudah bejalan baik, para siswa mulai nyaman belajar dengan Problem Based Learning. Keterlibatan guru dalam setiap kelompok diskusi juga sudah baik, pemberian reward juga sudah baik.

Refleksi tatap muka 2, siklus II, oleh kolaborator bersama peneliti sebagai berikut: proses pembelajaran dengan Problem Based Learning sudah baik, hal ini dapat dilihat dari beberapa indikator: banyak siswa yang aktif. Pendekatan guru dalam memantau dan mengamati siswa dengan teknik chennel sudah baik, situasi pembelajaran nyaman dan menyenangkan.

Manajemen waktu sudah baik, dan guru hendaknya melibatkan seluruh siswa dalam mengambil kesimpulan. Peningkatan proses pembelajaran juga dapat dilihat dan hasil analisis penilaian proses pembelajaran, keaktifan siswa juga dapat dilihat dan hasil analisis lembar observasi penilaian aspek afektif siswa.

Dalam penentuan kategori sebagai berikut:

\section{Penilaian Proses Pembelajaran}

Berdasarkan penilaian kolaborator terhadap proses pembelajaran Problem Based Learning, kolaborator memberikan jumlah skor 
98. Untuk menentukan jumlah butir aspek pengamatan atau 98:30 $=3,30$, maka penilaian proses pembelajaran kategorinya cukup.

Distribusi frekuensi skor terdapat pada tabel 5 berikut.

Tabel 5. Rekapitulasi Penilaian Proses Pembelajaran

\begin{tabular}{llcc}
\hline No. & Kategori & Frekuensi & Persentase (\%) \\
\hline 1 & Sangat Baik & 8 & 40 \\
2 & Baik & 12 & 60 \\
3 & Cukup & 0 & 0 \\
4 & Kurang & 0 & 0 \\
5 & Sangat Kurang & 0 & 0 \\
\hline & Jumlah & 20 & 100 \\
\hline
\end{tabular}

Berdasarkan tabel 5, hasil penilaian oleh kolaborator terhadap proses pembelajaran terdapat pada kategori baik sebesar 60,00\% dan $40 \%$ sangat baik.

\section{Penilaian Aspek Afektif Siswa}

Berdasarkan penilaian kolaborator terhdap aspek afektif siswa (instrumen II), diperoleh jumlah skor rata-rata 26,3. Untuk menentukan kategori penilaian aspek afektif siswa, jumlah skor rata-rata aspek pengamatan (26,3:6 = 4,38), maka kategorinya baik.

Refleksi dan kolaborator pada tatap muka 2, siklus II dapat kita rangkum dan kita fokuskan pada: Pembelajaran hendaknya difungsikan secara maksimal, diciptakan interaksi antar siswa, pemberian motivasi agar siswa aktif perlu ditingkatkan, pemberian pujian (reward) atau doorprice perlu ditingkatkan, pengelolaan kelas perlu ditingkatkan, menejemen waktu perlu diperhatikan sehingga proses pembelajaran berjalan lancar.

Tatap muka 3, siklus II, keaktifan siswa sudah mengalami peningkatan yang signifikan, Pembelajaran sudah berfungsi, semua siswa tidak membuka buku paket maupun Lembar Kerja Siswa. Dalam presentasi sudah banyak siswa yang menanggapi hasil diskusi kelompok lain, manajemen waktu sudah bagus sehingga hampir semua kelompok mempresentasikan hasil diskusinya. Hal ini sesuai dengan pengamatan yang dapat dirangkum sebagai berikut: interaksi antar siswa dalam kelompok Problem Based Learning sudah baik, siswa aktif menjawab pertanyaan baik dari guru maupun temannya. Guru mampu membawa proses pembelajaran dalam situasi inti dan menyenangkan. Diskusi sudah bejalan baik, para siswa mulai nyaman belajar dengan Problem Based Learning. Keterlibatan guru dalam setiap kelompok diskusi juga sudah baik, hampir semua siswa yang bisa menjawab pertanyaan dengan benar mendapat reward dari guru. Refleksi tatap muka 3, siklus II, oleh kolaborator bersama peneliti sebagai berikut: proses pembelajaran dengan Problem Based Learning sudah baik, hal ini dapat dilihat dari beberapa indikator: banyak siswa yang aktif. Pendekatan guru dalam memantau dan mengamati siswa demonchennel sudah baik, situasi pembelajaran nyaman dan menyenangkan. Manajemen waktu sudah baik, dan guru sudah mengarahkan seluruh siswa dalam mengambil kesimpulan. Peningkatan proses pembelajaran jutru dapat dilihat dan hasil analisis penilaian proses pembelajaran. berikut:

Dalam penentuan kategori sebagai

\section{Penilaian Proses Pembelajaran}

Berdasarkan perulaian kolaborator terhadap proses pembelajaran Problem Based Learning (menggunakan instrumen I), kolaborator memberikan jumlah skor 90 . Untuk menentukan kategori penilaian adalah jumlah butir aspek pengamatan atau 90:20 = 4,5, maka penilaian proses pembelajaran kategorinya baik. Distribusi frekuensi skor terdapat pada tabel 6 berikut.

Tabel 6. Rekapitulasi Penilaian Proses Pembelajaran

\begin{tabular}{llcc}
\hline No. & Kategori & Frekuensi & Persentase (\%) \\
\hline 1 & Sangat Baik & 10 & 50 \\
2 & Baik & 10 & 50 \\
3 & Cukup & 0 & 0 \\
4 & Kurang & 0 & 0 \\
5 & Sangat Kurang & 0 & 0 \\
\hline & Jumlah & 20 & 100 \\
\hline
\end{tabular}

Berdasarkan tabel 6, basil penilaian oleh kolaborator terhadap proses pembelajaran terdapat pada kategori baik sebesar $50 \%$ dan $50 \%$ sangat baik.

\section{Penilaian Aspek Afektif Siswa}

Berdasarkan penilaian kolaborator terhadap aspek afektif siswa (instrumen II), diperoleh jumlah skor rata-rata 27,85. Untuk menentukan kategori penilaian aspek afektif siswa, jumlah skor rata-rata aspek pengamatan $(27,85: 6=4,64)$, maka kategorinya baik.

Untuk mengetahui penilaian aspek kognitf, diakhir siklus diadakan ulangan harian, kemudian hasilnya dianalisis untuk mengetahui daya serap siswa baik secara individual maupun klasikal dan untuk mengetahui 
ketuntasan belajar siswa. Nilai terendah 73 dan nilai tertinggi 100 , nilai rata-rata 82,6 dan daya serap hasil ulangan harian siklus ke II ini sudah mencapai ketuntasan yaitu 82,6\%.

\section{SIMPULAN}

Berdasarkan hasil pembahasan pada penelitian tindakan kelas, didukung hasil analisis data penilaian proses pembelajaran, penilian aspek afektif siswa, hasil belajar siswa aspek kognitif dan hasil wawancara, maka kesimpulannya adalah Implementasi Metode Problem Based Learning, dalam upaya meningkatkan hasil belajar akuntansi pada siswa di SMAN 1 Pengasih sangat cocok digunakan sebagai metode pembelajaran, peningkatan tersebut pada:

1. Interaksi antara guru dan siswa menjadi lebih komunikatif

2. Hasil belajar siswa menjadi meningkat yaitu $82,6 \%$

3. Aspek afektif siswa menjadi aktif mengikuti mata pelajaran Akuntansi

\section{SARAN}

Berdasarkan kesimpulan di atas maka dikemukakan sara-saran sebagai berikut: dalam pembelajaran ekonomi guru dianjurkan kreatif, inovatif, menggunakan media dan metode yang berbeda dari biasanya, agar proses pembelajaran ekonomi menjadi menarik, menyenangkan dan bermakna.

\section{DAFTAR PUSTAKA}

Block, J. (1971). Mastery Learning. New York: Holt, Rinerhart and Witson, Inc.

Bums, A. (1999). Collaorative action research for english language teachers. Cambrige: University Press.

Endang Mulyadi, E. K. (2016). Ekonomi. Jakarta: Yudhistira.

Feryanto, A. (2010). Buku Panduan Pendidik Ekonomi untuk SMA/MA. Klaten: Intan Pariwara.

Maksum Habibi, d. (1997). Pelajaran Akuntansi. Jakarta: Yudhistira.

Mulyadi, E. (2011). Akuntansi 2. Jakarta: Yudhistira.

Trianto. 2011. Mendesain Model Pembelajaran Inovatif-Progresif. Jakarta: Kencana Prenada Media Group.

Amir, M. Taufiq. 2010. Inovasi Pendidikan Melalui Problem Based Learning. Jakarta: Kencana Prenada Media Group. Nasution. 2011. Berbagai Pendekatan dalam Proses Belajar dan Mengajar. Jakarta: Bumi Aksara. Sardiman, A.M. 2011. Interaksi dan Motivasi Belajar Mengajar. Jakarta: Raja Grafindo Persada. 